\title{
Anatomical Aspects of Permanent Geminate Superior Central Incisives
}

\author{
Aspectos Anatómicos de los Incisivos Centrales Superiores Permanentes Geminados
}

"Katia Simone Alves dos Santos; ${ }^{* *}$ Carla Cabral dos Santos Accioly Lins;

${ }^{* * *}$ Fábio Almeida-Gomes; ${ }^{* * *}$ Rosana Maria Coelho Travassos \& ${ }^{* * *}$ Roberto Alves dos Santos

SANTOS, K. S. A.; LINS, C. C. S. A.; ALMEIDA-GOMES, F.; TRAVASSOS, R. M. C. \& SANTOS, R. A. Anatomical aspects of permanent geminate superior central incisives. Int. J. Morphol., 27(2):515-517, 2009.

SUMMARY: The dental gemination is a morphological alteration that can occur during the development of the dental germ, resulting in a total or partial formation of two teeth which are not completely separate. The aim of this work was to relate an unusual case of gemination by the periapical radiography of superior central incisive in the permanent dentition.

KEY WORDS: Permanent dentition; Periapical radiography; Dental anomaly.

\section{INTRODUCTION}

The dental morphological variations occur due to a failure during the phases of the development of the tooth. According to the phase in which happened the alteration, the tooth can show variations of form like: "dens in dente", taurodontism, dilaceration, fusion and gemination. These alterations are more common in superior lateral incisives, inferior premolars and superior molars (Barbosa et al., 2005).

The gemination is known as an attempt of the division of a dental germ resulting in an incomplete formation of two teeth, forming one tooth with a diameter larger than is usual; its crown shows a low deep groove from incisal to gingival and radiographically, there is only one root as well as only one root canal. It is different from the fusion that has the inverse process, two teeth linked by the enamel and the dentine form one tooth which can have a normal or bigger size but with two roots and two separate canals (Neville et al., 2004).

The dental fusion and gemination together represent $1 \%$ of dental anomalies (Aragones et al., 1994; Gonçalves et al., 2002) affirmed that these alterations can be frequently found and therefore the professional of Odontology must diagnose and treat it correctly.

\section{RELATE OF A CASE}

A 19 years old patient N.P.N. male, came to the Service of Specialization in Endodontics of Pernambuco University / Odontology College, Recife-PE, Brazil; relating pain in the superior central incisive. During the clinical exam it was emphasized: alteration of the color of dental crown and fistula in the vestibular mucosa next to the right superior central incisive; a diameter mesiodistal larger than is usually found (Fig. 1), as well as the absence of sensation to thermal stimulus in both teeth. The radiographic exam emphasized a wide pulp cavity what suggests the presence of an anomaly of development (gemination) with incomplete formation of root apex (Fig. 2). Afterwards it were realized the urgency procedures and the following endodontic treatment.

\section{DISCUSSION}

A disorder of growth or development in the buccal anatomical structures that results in anything different from normal is called anomaly, Alvares \& Tavano (2000). During the odontogenesis, the dental anomalies can be produced by nutritional deficiency, endocrine influences, infectious/

\footnotetext{
*Dept. of Endodontics, State University from Paraíba-PB, Brazil.

** Dept. of Anatomy, Federal University of Pernambuco and Dept. of Endodontics, University of Pernambuco, Fac. of Odontology, Brazil.

**** Department of Endodontics, University of Pernambuco, Faculty of Odontology, Brazil.
} 
inflammatory processes, excessive ingestion of medicines, hereditary or congenital diseases, local traumas and by ionizing radiation ( Castro et al., 2000 and Neville et al.).

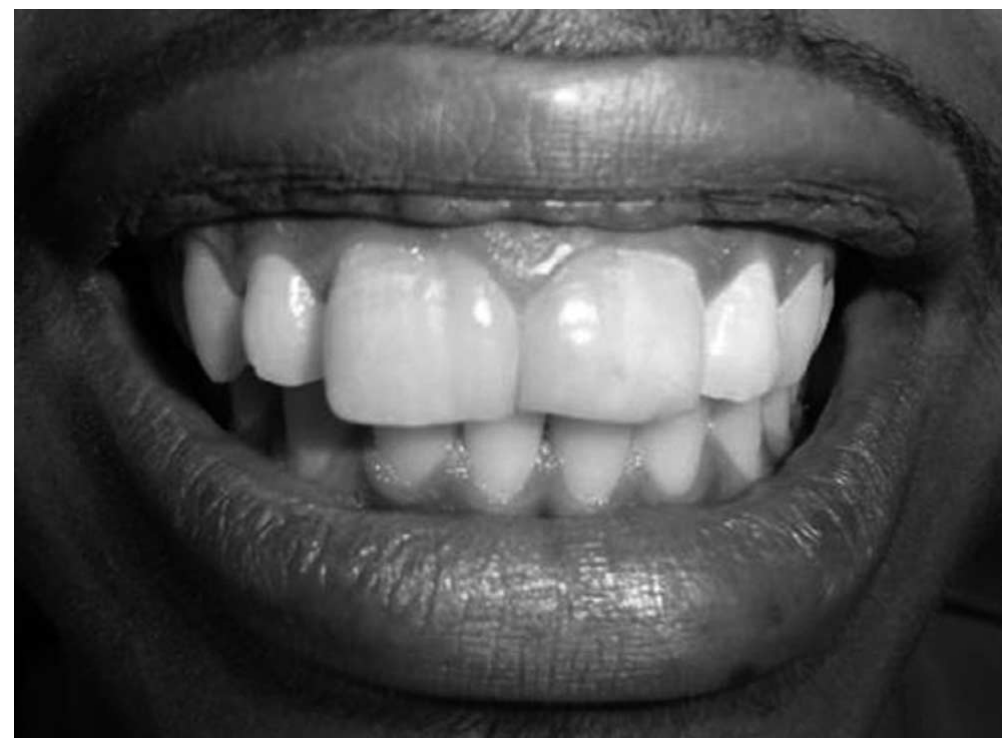

Fig. 1. Clinical aspect of superior central incisive permanent geminated.

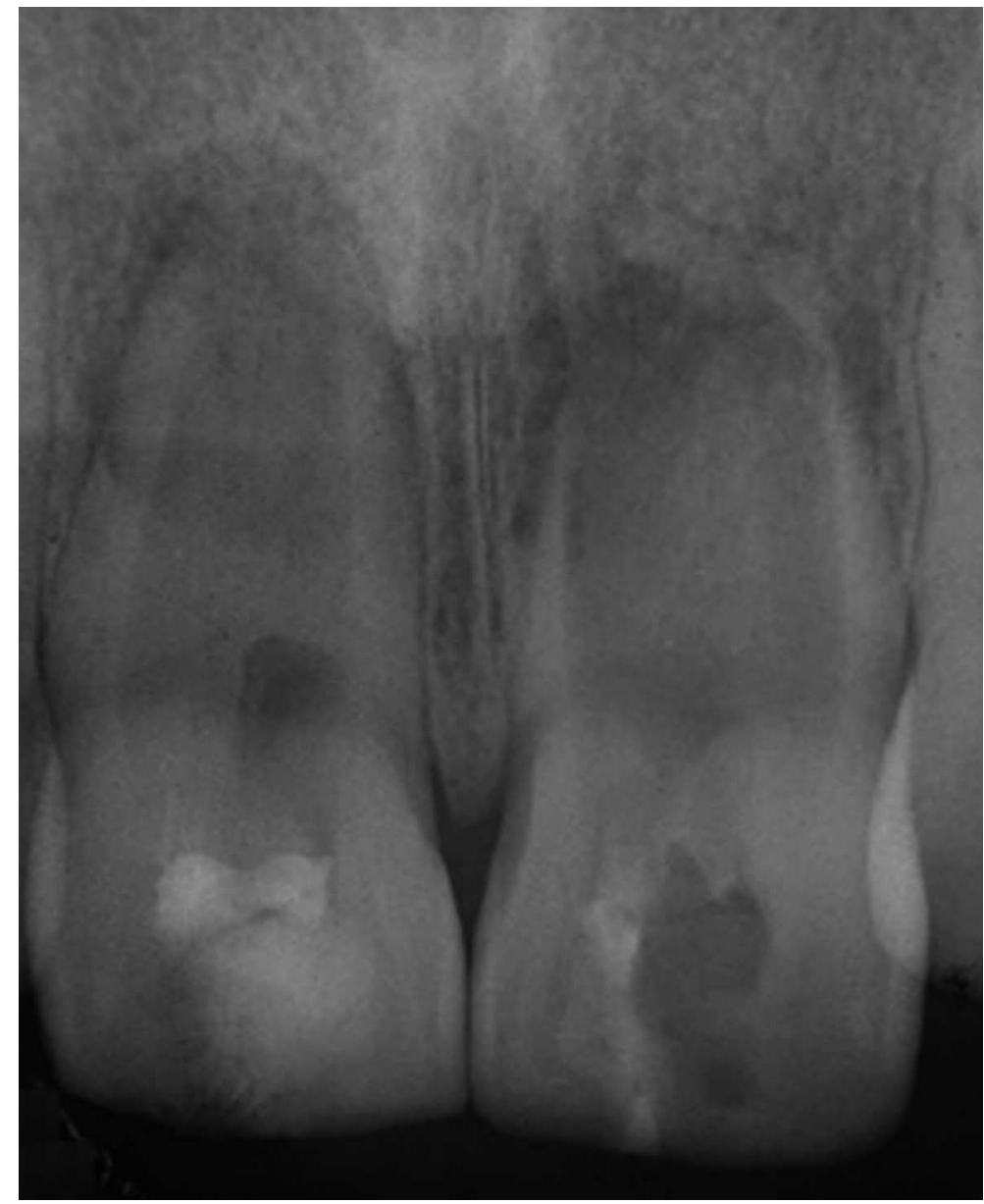

Fig. 2. Periapical radiography of superior central incisive permanent geminated.
The dental gemination is a morphological alteration that sometimes is confused with fusion (Ferraz et al., 2001; Neville et al.), but radiographically the gemination shows only one root canal with a wide pulp cavity.

The authors do not agree according to its frequency in dental groups; one group affirm that the more affected teeth are the lateral superior incisives, inferior premolars and superior molars (Barbosa et al.); the others affirm that the more affected teeth are the inferior incisives (Tommasi, 1989).

According to its clinical characteristics, Neville et al., related that the geminated teeth shows itself anatomical correctly, however too much increased; it can show a bifid crown with two roots completely separate, which was a fact observed in our clinical case.

Nik-Hussein \& Abdul Majid (1996) and Balarotti (2003) emphasized that the dental anomalies present in deciduous dentition are associated with their permanent successors and that the knowledge of these variations help the dental surgeons in the clinical treatment.

SANTOS, K. S. A.; LINS, C. C. S. A.; ALMEIDAGOMES, F.; TRAVASSOS, R. M. C. \& SANTOS, R. A. Anatomical aspects of permanent geminate superior central incisives. Int. J. Morphol., 27(2):515-517, 2009.

RESUMEN: La geminación dental es una alteración morfológica que puede suceder durante el desarrollo dental del embrión, dando por resultado la formación parcial o total de dos dientes que no estén separados totalmente. El objetivo de este trabajo fue describir un caso infrecuente de geminación, a través de la radiografía periapical en incisivos centrales superiores en la dentición permanente.

PALABRAS CLAVE: Dentición permanente; Radiografía dentaria; Anormalidad dentaria. 
SANTOS, K. S. A.; LINS, C. C. S. A.; ALMEIDA-GOMES, F.; TRAVASSOS, R. M. C. \& SANTOS, R. A. Anatomical aspects of permanent geminate superior central incisives. Int. J. Morphol., 27(2):515-517, 2009.

\section{REFERENCES}

Alvares, L. C. \& Tavano, O. Aspectos radiográficos das anomalias dentárias e maxilares. In: Freitas, A.; Rosa, J. E. \& Souza, I. F. Radiografia Odontológica. $5^{\mathrm{a}}$ ed. São Paulo, Artes Médicas, 2000. pp. 447-62.

Aragones, A.; Lima, J. E. O.; Machado, M. A. A. M. \& Cunha, R. F. Fusion in deciduous teeth: management and case relate. Revista da Faculdade de Odontologia de Bauru, 2(3):1-4, 1994.

Balarotti E. Estudo da prevalência de fusão e geminação na dentição decídua e possível correlação com anomalias na dentição permanente. Tese Mestrado, USP, Bauru, Brasil, 2003.

Barbosa, C. K. R.; Lopes, L. D.; Freitas, P. H. R. de; Borges, P. G.; Silva, R. F. C.; Cunha, M. S. \& Scelza, M. F. Z. Morfological in the pulpar chamber that can interfere in the endodontic treatment. UFES rev. odontol., 7(2):47$51,2005$.

Gonçalves, M.; Rossi, C. G. \& Gonçalves, A. Fusion and gemination of teeth: clinical and radiographic features. Rev. da ABRO, 3(1):15-8, 2002.

Ferraz J. A.; de Carvalho Junior J. R.; Saquy, P. C.; Pécora, J. D. \& Sousa-Neto M. D. Dental anomaly: dens evaginatus (talon cusp). Braz. Dent. J., 12(2):132-4, 2001.

Nik-Hussein, N. N. \& Abdul Majid, Z. Dental anomalies in the primary dentition: distribution and correlation with the permanent dentition. J. Clin. Pediatr. Dent., 21(1):159, 1996.

Neville, B. W.; Damm, D. D.; Allen, C.M. \& Bouquot, J. E. Patologia Oral e Maxilofacial. $2^{\mathrm{a}}$ Ed. Rio de Janeiro, Guabara Koogan, 2004. p.789.

Tommasi, A. F. Diagnóstico em Patologia Bucal. $2^{\mathrm{a}}$ Ed. Pancast, 1989. p. 660.
Correpondence to:

Prof. Carla Cabral dos Santos Accioly Lins

Department of Anatomy

Universidade Federal de Pernambuco

Rua manuel de carvalho, $n^{\circ} 310$, apt 303 , aflitos

CEP 52050-370

Recife- PE, BRASIL

Email: cabralcarla1@hotmail.com

Received: 18-06-2008

Accepted: 18-04-2009 
